Chapman University

Chapman University Digital Commons

Food Science Faculty Articles and Research

Food Science

$10-21-2015$

\title{
Antioxidant Effect of Spent, Ground, and Lyophilized Brew from Roasted Coffee in Frozen Cooked Pork Patties
}

Katrina Maryse Malixi Jully

Chapman University, jully100@mail.chapman.edu

Criselda Toto

Chapman University, toto@chapman.edu

Lilian Were

Chapman University,were@chapman.edu

Follow this and additional works at: http://digitalcommons.chapman.edu/food_science_articles

Part of the Food Processing Commons, Meat Science Commons, and the Other Food Science Commons

\section{Recommended Citation}

Jully, K.M.M., Toto, C.S., Were, L., 2016. Antioxidant effect of spent, ground, and lyophilized brew from roasted coffee in frozen cooked pork patties. LWT - Food Science and Technology 66, 244-251. doi:10.1016/j.lwt.2015.10.046

This Article is brought to you for free and open access by the Food Science at Chapman University Digital Commons. It has been accepted for inclusion in Food Science Faculty Articles and Research by an authorized administrator of Chapman University Digital Commons. For more information, please contact laughtin@chapman.edu. 


\section{Antioxidant Effect of Spent, Ground, and Lyophilized Brew from Roasted Coffee in Frozen Cooked Pork Patties}

\section{Comments}

NOTICE: this is the author's version of a work that was accepted for publication in LWT - Food Science and Technology. Changes resulting from the publishing process, such as peer review, editing, corrections, structural formatting, and other quality control mechanisms may not be reflected in this document. Changes may have been made to this work since it was submitted for publication. A definitive version was subsequently published in LWT - Food Science and Technology, volume 66, in 2016. DOI: 10.1016/j.lwt.2015.10.046

The Creative Commons license below applies only to this version of the article.

\section{Creative Commons License}

\section{(c) 1 (1) 90}

This work is licensed under a Creative Commons Attribution-Noncommercial-No Derivative Works 4.0 License.

\section{Copyright}

Elsevier 


\section{Accepted Manuscript}

Antioxidant effect of spent, ground, and lyophilized brew from roasted coffee in frozen cooked pork patties

Katrina Maryse Malixi Jully, Criselda S. Toto, Lilian Were

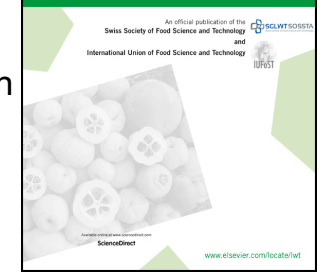

PII:

S0023-6438(15)30264-4

DOI:

10.1016/j.Iwt.2015.10.046

Reference: YFSTL 5041

To appear in: $\quad$ LWT - Food Science and Technology

Received Date: 28 July 2015

Revised Date: 2 October 2015

Accepted Date: 19 October 2015

Please cite this article as: Malixi Jully, K.M., Toto, C.S., Were, L., Antioxidant effect of spent, ground, and lyophilized brew from roasted coffee in frozen cooked pork patties, LWT - Food Science and Technology (2015), doi: 10.1016/j.Iwt.2015.10.046.

This is a PDF file of an unedited manuscript that has been accepted for publication. As a service to our customers we are providing this early version of the manuscript. The manuscript will undergo copyediting, typesetting, and review of the resulting proof before it is published in its final form. Please note that during the production process errors may be discovered which could affect the content, and all legal disclaimers that apply to the journal pertain. 
1 Antioxidant Effect of Spent, Ground, and Lyophilized Brew from Roasted Coffee in Frozen

2 Cooked Pork Patties

3

4 Katrina Maryse Malixi Jully ${ }^{\mathrm{a}}$, Criselda S. Toto ${ }^{\mathrm{b}}$ and Lilian Were ${ }^{\mathrm{a} *}$

5

$6 \quad{ }^{\mathrm{a}}$ Food Science Program, Schmid College of Science and Technology, Chapman University, 1

7 University Drive, Orange, CA 92866, USA

$8{ }^{\mathrm{b}}$ Mathematics and Computer Science, Chapman University, 1 University Drive, Orange, CA

9 92866, USA

10

11

12

13

14

15

16

17

*Corresponding Author

18

Address: Food Science Program, Schmid College of Science and Technology, Chapman

19 University, 1 University Drive, Orange, CA 92866, USA

20 Telephone: (714) 744-7895

21 Fax Number: 714-532-6048

22 E-mail: were@ chapman.edu 


\section{ABSTRACT}

The ability of light and dark roasted coffee $(1 \mathrm{~g} / \mathrm{kg})$ in varying application forms (spent ground [SCG], whole ground [WGC], or lyophilized brew [LBC]) to inhibit lipid and protein oxidation in cooked pork patties stored at $-18^{\circ} \mathrm{C}$ was monitored over 3 months. Malondialdehyde (MDA) for the negative control (NC) increased from 0.31 to $1.11 \mathrm{mg} \mathrm{MDA} / \mathrm{kg}$ pork over 3 months, while pork with coffee or rosemary oleoresin had lower values at month 3 (0.054-0.40 mg MDA/kg pork). The NC had the highest values for hexanal, octanal, and nonanal $(2.59,0.10$, and $0.13 \mathrm{mg} / \mathrm{kg}$ pork, respectively), while light and dark LBC in pork inhibited hexanal (0.37 and $0.39 \mathrm{mg} / \mathrm{kg}$ pork), octanal (0.017 and $0.021 \mathrm{mg} / \mathrm{kg}$ pork), and nonanal $(0.036$ and $0.048 \mathrm{mg} / \mathrm{kg}$ pork) to the same extent as rosemary oleoresin at month $3(0.30,0.015,0.036 \mathrm{mg}$ aldehyde $/ \mathrm{kg}$ pork, respectively). Thiol content for all treatments remained relatively stable from month 0 to 3 (0.56-0.96 to $0.67-1.02)$, while metmyoglobin slightly increased (49-55\% to $55-56 \%)$ over 3 months. The results suggest that adding coffee neither inhibited nor promoted protein oxidation in cooked pork patties but inhibited lipid oxidation resulting in comparable values to pork with added rosemary oleoresin.

Key Words: Coffee; Cooked pork; Frozen storage; Oxidation. 


\section{Introduction}

The efficiency and convenience offered by precooking products makes precooked pork appealing in today's fast-paced lifestyle (Nolan, Bowers, \& Kropf, 1989). While the convenience appeals to consumers, precooking before packaging and storing can accelerate oxidation, deteriorating product quality (Dai, Lu, Wu, Lu, Han, Liu, et al., 2014; Kingston, Monahan, Buckley, \& Lynch, 1998; Salminen, Estevez, Kivikari, \& Heinonen, 2006; Sasse, Colindres, \& Brewer, 2009). Cooking destroys the integrity of cell membranes releasing phospholipids, and inactivates several protective antioxidants e.g. catalase (Rhee, Anderson, \& Sams, 1996). In addition, hemoproteins such as myoglobin are denatured allowing the release of the prooxidant iron, which can result in the warmed-over flavor (WOF). The WOF becomes predominant with precooking and is characterized by undesirable organoleptic qualities (Rojas \& Brewer, 2007). These adverse qualities are due to the secondary products of lipid oxidation (LOX) such as hexanal, octanal, and nonanal. Destruction of cell membranes, decreased catalase activity, and the increase in nonheme iron can elevate the rate of LOX in cooked pork, therefore, it is important to apply strategies to prolong the shelf-life of cooked pork products (FernandezLopez, Sevilla, Sayas-Barbera, Navarro, Marin, \& Perez-Alvarez, 2003; Rhee, Anderson, \& Sams, 1996).

Multiple preservation methods are applied to maintain meat quality, including storage temperature and antioxidants. Frozen storage is an effective method since low temperatures slow down oxidative reactions. However, freezing does not completely inhibit physical and chemical reactions causing discoloration and oxidative rancidity over time. Antioxidants (AOXs) can be added to combat LOX and protein oxidation (POX). Rosemary has become the industry natural AOX based on overall effectiveness in pork and other meat matrices (Georgantelis, Ambrosiadis, 
Katikou, Blekas, \& Georgakis, 2007; Kim, Cadwallader, Kido, \& Watanabe, 2013). The key bioactive antioxidant rosemary compounds are carnosol, carnosic and rosmarinic acid which readily donate their hydrogens acting as free radical scavengers. Recently, roasted coffee was shown to inhibit LOX as effectively as rosemary oleoresin in refrigerated beef with added salt, a known prooxidant of LOX (Lin, Toto, \& Were, 2015). The bioactivity of roasted coffee is attributed to a combination of hydroxycinnamic chlorogenic acids (CGAs), and Maillard reaction products (MRPs), which scavenge free radicals and chelate metal catalysts of LOX and POX (Del Pino-Garcia, Gonzalez-SanJose, Rivero-Perez, \& Muniz, 2012; Delgado-Andrade, RufianHenares, \& Morales, 2005; Farah, 2012). Concentrations of AOX compounds differ in whole ground coffee (WGC), lyophilized brew coffee (LBC), or spent coffee ground (SCG) and by roast degrees. Spent coffee, from home or restaurant preparations, are of particular interest since substantial bioactive compounds may remain due to short brewing time and coffeemaker filter (Ludwig, Sanchez, Caemmerer, Kroh, Paz De Pena, \& Cid, 2012). Furthermore, SCG are considered waste products hence repurposing into a sustainable preservation method can result in economic gain for the meat and coffee industry, while still producing a safe, quality pork product.

To our knowledge, no studies have investigated the effectiveness of SCG as an antioxidant in food and limited studies have reported the effects of roasted coffee in food matrices: Nissen, Byrne, Bertelsen, \& Skibsted (2004) in cooked frozen pork, Budryn \& Nebesny (2013) in cookies and chocolate, and Lin, Toto, \& Were (2015) in raw refrigerated beef. The experimental objective was to determine the optimal combination of roast degree (light or dark) with application form (SCG, WGC, LBC) for the greatest AOX effect to preserve shelf life and quality in frozen precooked pork. 
87

88

89

90

91

92

\section{Material and Methods}

\subsection{Chemicals}

Aldehyde and 4-heptanone standards, bovine albumin serum, biuret reagent, HPLC grade methanol, water, formic acid, acetonitrile, ferrous sulfate heptahydrate and sodium phosphate dibasic anhydrous were purchased from Fisher Scientific (Tustin, CA, USA). Sodium phosphate monobasic was from Spectrum Chemical (Gardena, CA, USA). Ellman's reagent 5, 5'dithiobis(2-nitrobenzoic acid), EDTA, ferrozine , trichloroacetic acid (TCA), 2-Thiobarbituric acid (TBA), and 1, 1, 3, 3,-tetramethoxypropane (TMP) were purchased from Sigma-Aldrich (St. Louis, MO, USA).

\subsection{Preparation of coffee and pork treatments}

Green Colombia Primeval coffee beans obtained from Rose Park Roasters (Long Beach, $\mathrm{CA}$, USA) were roasted to produce a light $\left(10 \min 32 \mathrm{~s}\right.$ to $\left.210^{\circ} \mathrm{C}\right)$ and dark $\left(12 \min 8 \mathrm{~s}\right.$ to $\left.235^{\circ} \mathrm{C}\right)$ roast. Whole coffee beans were ground (Cuisinart "Grind Central" Coffee Grinder, East Windsor, NJ, USA) and passed through a $1.0 \mathrm{~mm}$ sieve (18-mesh size) resulting in WGC. Lyophilized brewed coffee was prepared following the methods indicated by Budryn \& Nebesny (2013) with modifications. Coffee brew was prepared by heating water to $90^{\circ} \mathrm{C}$, then adding ground coffee to water at a 1 to 6 ratio. The solution was held at $90^{\circ} \mathrm{C}$ for five min with constant stirring, filtered with a paper coffee filter to yield liquid brew, which was then lyophilized (Dura-Dry mP manifold lyophilizer, FTS Systems, model \#FD2085C0000, Stone Ridge, NY, USA) to yield LBC. The remaining solid grounds from coffee brew extraction was lyophilized and used as SCG. Coffee was stored at $<0^{\circ} \mathrm{C}$ before use. Before incorporation into minced pork, all coffee forms were passed through a $1.0 \mathrm{~mm}$ sieve (18-mesh size). 
Meat was prepared in accordance to AOAC Official method 983.18 (AOAC, 2010) with modifications. Minced sirloin pork chops from Butcher hogs, averaging 6 months in age, 95.34 $\mathrm{kg}$ live weight at the time of slaughter, was supplied and prepared at Farmer John® facilities (Vernon, CA, USA). Pork meat was minced in an industrial-sized chopper, and refrigerated $\left(<4^{\circ} \mathrm{C}\right)$ overnight prior to addition of coffee or rosemary oleoresin the following day. All treatments, negative control (NC), rosemary oleoresin [RO; Herbalox ${ }^{\circledR}$ HT-25 from Kalsec Inc. (Kalamazoo, MI, USA); $2 \mathrm{~g} / \mathrm{kg})]$, SCG, WGC, and LBC of light $(1 \mathrm{~g} / \mathrm{kg})$ and dark $(1 \mathrm{~g} / \mathrm{kg})$ roasts were mixed using a Hobart Legacy HL200 20 Qt mixer (Troy, OH, USA) for two min resulting in eight different treatment samples with uniform processing. This process was repeated per treatment in order to achieve true duplicates. The pork was transferred to polyethylene plastic bags, placed into cardboard boxes, and transported $56 \mathrm{~km}$ from Vernon to Orange, CA, USA.

\subsection{Cooked pork preparation}

Pork meat was stored at $4^{\circ} \mathrm{C}$ until ready to be formed into pork patties $(\sim 3 \mathrm{~h})$. Pork was prepared and cooked following the Research Guidelines for Cookery, Sensory Evaluation, and Instrumental Tenderness Measurements of Fresh Meat (AMSA, 1995) with modifications. Pork patties (100 $\pm 1 \mathrm{~g})$ were molded $(11.5 \mathrm{~cm}$ diameter, $1.25 \mathrm{~cm}$ thickness $)$ then cooked on two electric griddles (ToastMaster®, Model \#TG21W \& \# TM161GR, St. Louis, MO, USA) set to $205^{\circ} \mathrm{C}$ for $3.5 \mathrm{~min}$ on each side or until internal temperature reached a minimum of $72^{\circ} \mathrm{C}$ in the center of the patty. Patties were cooled at $22-25^{\circ} \mathrm{C}$ before being individually placed into oxygen permeable zipper bags (polyethylene, $16.5 \mathrm{~cm}$ x $14.9 \mathrm{~cm}$ ). Patties were stored at $-18^{\circ} \mathrm{C}$ until ready to be analyzed. Patties from each treatment were transferred from $-18^{\circ} \mathrm{C}$ to $4^{\circ} \mathrm{C}$ to thaw for $12 \mathrm{~h}$, and were hand mixed for $30 \mathrm{~s}$ prior to analysis. 
131

132

\subsection{Chlorogenic, Maillard reaction products, and iron chelating ability}

\section{Quantification}

Spent, ground, and lyophilized brew of light, medium, and dark roasted coffee were added to deionized water at $1 \mathrm{~g} / 100 \mathrm{~mL}$ to test MRPs and $0.1 \mathrm{~g} / 100 \mathrm{~mL}$ to test iron chelating ability and CGA, then incubated for 2 hours at $22^{\circ} \mathrm{C}$. Quantification of CGA in the various forms of coffee were measured via HPLC following protocols by Lin, Toto, \& Were (2015). A C18 column (Kinetex, 2.6u C18 100A, 100 x 4.60 mm, Phenomenx, Torrance, CA, USA) was used at $30^{\circ} \mathrm{C}$ using a flow rate of $1.5 \mathrm{~mL} / \mathrm{min}$ with mobile phase (A) $1 \mathrm{mg} / \mathrm{mL}$ formic acid in HPLC water and (B) HPLC grade acetonitrile. Sample was injected (5 $\mu \mathrm{L})$ with starting conditions of A/B, 95/5 held for 10 minutes. Solvent A was linearly decreased to $85 \%$ within 1 min and held for 0.5 min before returning back to starting conditions within $2.5 \mathrm{~min}$. A standard curve of chlorogenic acid (0-0.6 mM) was used to quantify chlorogenic acid detected at $330 \mathrm{~nm}$.

Quantification of MRPs and ferrous iron chelating ability were measured following protocols by Teets and Were (2008).

\subsection{Thiobarbituric acid reactive substances (TBARS) measurement}

The TBARS assay was prepared as described by Lin, Toto, \& Were (2015) with modifications. The supernatant $(5 \mathrm{~mL})$ was reacted with $5 \mathrm{~mL}$ of $0.02 \mathrm{M}$ TBA solution in glass test tubes. Recovery values were determined by spiking additional meat samples (randomly chosen each testing day) with $0.5 \mathrm{~mL}$ of 0.15 or $0.45 \mathrm{mM}$ TMP solution to achieve final TMP concentration of 0.006 and $0.018 \mathrm{mM}$ after $12.0 \mathrm{~mL}$ of TCA had been added. These mixtures were vortexed and centrifuged alongside the other samples. A TMP standard curve $(0-7.5 \mathrm{nmol}$ $\mathrm{MDA} / \mathrm{mL}$ ) was used to quantify MDA after $16 \mathrm{~h}$ incubation at $22-25^{\circ} \mathrm{C}$ in the dark. Absorbance 
was measured at $532 \mathrm{~nm}$ and $600 \mathrm{~nm}$, with the latter accounting for any potential turbidity, using a FLUOstar Omega multimode microplate reader (Cary, NC, USA).

\subsection{Purge and trap gas chromatography measurement of volatile aldehydes}

Volatile compounds from pork samples were extracted via distillation and measured by gas chromatography $(\mathrm{GC})$ using internal standard 4-heptanone $(50 \mu \mathrm{L} / \mathrm{L})$ following protocols by Lin, Toto, \& Were (2015). Samples were analyzed in duplicate and hexanal, octanal, and nonanal concentrations were expressed as $\mathrm{mg} / \mathrm{kg}$ based on internal response factor of the internal standard and each respective aldehyde.

\subsection{Free thiol content measurement}

Free thiol content was measured following method by Eymard, Baron, \& Jacobsen (2009) with modifications. Protein was extracted from pork $(5.0 \pm 0.1 \mathrm{~g})$ and vortexed for $30 \mathrm{~s}$ with 25 $\mathrm{mL}$ of $0.1 \mathrm{M}$ phosphate buffer $(\mathrm{pH} 7.4)$ in $50 \mathrm{~mL}$ centrifuge tubes. After centrifugation $(3,000$ $\mathrm{rpm} / 127.8 \mathrm{~g}$ ) for $15 \mathrm{~min}$ at $4^{\circ} \mathrm{C}$, the supernatant was filtered through eight layers of cheesecloth to obtain protein homogenates. For each treatment, $400 \mu \mathrm{L}$ of homogenate, $600 \mu \mathrm{L}$ DI water, and $14.3 \mu \mathrm{L}$ of $0.01 \mathrm{M}$ DTNB in 0.2 M EDTA was added to a microcentrifuge tube and incubated in a water bath $\left(40^{\circ} \mathrm{C}\right)$ for $15 \mathrm{~min}$. The Biuret method was used to determine average protein extracted using $0.1 \mathrm{M}$ phosphate buffer. The protein concentration in solution was determined to be $0.037 \mathrm{~g} / \mathrm{mL}$. Concentration of free thiol content expressed in $\mu$ mol thiol $/ \mathrm{g}$ protein was read in triplicates at $412 \mathrm{~nm}$ using a molar extinction coefficient of $13,600 \mathrm{M}^{-1} \mathrm{~cm}^{-1}$.

\subsection{Quantification of metmyoglobin formation}

Metmyoglobin concentration was calculated as described by Tang, Faustman, \& Hoagland (2004). Extracted proteins from section 2.7 for each treatment were aliquoted in 
175

176

177

178

179

180

181

182

183

184

185

186

187

188

189

190

191

192

193

194

195

196

triplicate and absorbance was measured at 503, 525, 557, and $582 \mathrm{~nm}$. Percent metmyoglobin was calculated by the equation:

$[\%$ metmyoglobin $]=\left(-0.159 R_{1}-0.085 R_{2}+1.262 R_{3}-0.520\right) * 100$

where $\mathrm{R}_{1}=\mathrm{A}_{582} / \mathrm{A}_{525}, \mathrm{R}_{2}=\mathrm{A}_{557} / \mathrm{A}_{525}, \mathrm{R}_{3}=\mathrm{A}_{503} / \mathrm{A}_{525}$.

\subsection{Statistical analysis}

Duplicates frozen cooked pork patties with coffee in pork treatments $(1 \mathrm{~g} / \mathrm{kg}$ of each coffee combination), positive control (2 g/kg Herbalox ${ }^{\circledR}$ HT-25), and negative control (no AOXs added) were monitored over 3 months. General linear model procedure in Statistical Analysis 9.3 Software (SAS Institute, 2011) was used to determine the differences in means between treatments per month for TBARS, GC, free thiol content, and percent metmyoglobin (MetMb). Analysis of variance (ANOVA) and Duncan's multiple range test were performed to determine whether a statistical significance existed. In addition, Pearson's correlation coefficients between each assay were determined. A level of significance of $\alpha=0.05$ was used throughout analysis.

\section{Results and Discussion}

\subsection{Antioxidants in coffee}

The LBC form for all roast degrees had the highest CGA amongst all application forms, while SCG had the least (Table 1), attributed to the higher solubility of low molecular weight compounds extracted from coffee grounds into the brew. The majority of CGAs remained in the brew, however, extraction of all CGA was incomplete as noted by the amount left in the SCG.

Ludwig, Sanchez, Caemmerer, Kroh, Paz De Pena, \& Cid (2012) reported that brew time and temperature affects the final concentration of CGA extracted. The incomplete removal of 
phenolic compounds into the brew supports the hypothesis that spent coffee could be utilized as an AOX. Increasing roast degree decreased concentrations of CGA as expected since roasting degrades CGAs or incorporates them into MRPs (Nicoli, Anese, Manzocco, \& Lerici, 1997). whereas dark roasted coffee showed similar values of MRPs to the medium roast (Table 1). With the exception of light SCG, all roasts of SCG and WGC forms reported similar values of MRPs, since the majority of water soluble MRPs are also extracted into the brew form (Bravo, Juaniz, Monente, Caemmerer, Kroh, Paz De Pena, et al., 2012). Due to the extraction of water soluble MRPs into the brew, this also resulted in higher levels of metal chelation values for LBC compared to the spent and ground form. However, there was a decreasing trend with increasing roast degree in regards to LBC, which was consistent with Lin, Toto, \& Were (2015). In regards to the other application forms, there was an increase in metal chelation with increasing roast degree for SCG, while WGC maintained similar values with increasing roast degree.

\subsection{Extent of lipid oxidation measured by thiobarbituric acid reactive substances}

The TBARS values reached the highest levels in month 2, increasing from 0.031-0.31 mg

$212 \mathrm{MDA} / \mathrm{kg}$ pork in month 0 to $0.070-1.15 \mathrm{mg}$ MDA/kg pork in month 2 (Fig 1). In month 3

213 amongst treatments, TBARS levels remained the same (light and dark LBC, light and dark

214 WGC, and negative control) or decreased (light and dark SCG, rosemary oleoresin) from month

215 2. Despite the decrease observed from month 2 to 3 for some treatments, there was an overall

216 increase from initial to end of storage with increases ranging from 43-270\%. This trend was

217 similar to the results reported by Sasse, Colindres, \& Brewer (2009) and Abd El-Alim, Lugasi,

218 Hovari, \& Dworschak (1999). While oxidative reactions are significantly inhibited in frozen

219 storage, LOX reactions can still occur, although at slower rates as noted by the overall increase 
during storage (Rhee, Anderson, \& Sams, 1996; Sasse, Colindres, \& Brewer, 2009). The decrease from month 2 to 3 could be attributed to (1) MDA decomposition to other organic byproducts such as alcohols and acids, or (2) decomposition by bacteria such as Pseudomonas, which attack carbonyl compounds like MDA (Georgantelis, Ambrosiadis, Katikou, Blekas, \& Georgakis, 2007). The former is the most probably pathway since growth of Pseudomonas, a psychrotrophic bacteria, would be negligible at frozen conditions. Furthermore, secondary products of LOX, including MDA, can react with free amino groups from proteins. Since the TBARS assay measures only free MDA, the MDA-protein interaction can result in lower TBARS values (Viljanen, Kivikari, \& Heinonen, 2004).

Negative control exhibited higher TBARS values throughout storage compared with other treatments $(\mathrm{p} \leq 0.05)$, suggesting that AOX compounds from rosemary oleoresin and coffee inhibited MDA formation. By month 3, all pork samples with added coffee presented similar TBARS values (0.054-0.22 mg MDA/kg pork) to rosemary oleoresin $(0.070 \mathrm{mg} \mathrm{MDA} / \mathrm{kg}$ pork), with the exception of light WGC which reported slightly higher MDA concentrations by the end of storage $(0.40 \mathrm{mg} \mathrm{MDA} / \mathrm{kg}$ pork). Despite the overall increase over time in TBARS, all coffee treated pork, with the exception of light SCG, never exceeded the threshold of when rancidity can be detected; $0.5 \mathrm{mg}$ MDA/kg of pork (Gray \& Pearson, 1987; Sheard, Enser, Wood, Nute, Gill, \& Richardson, 2000). Negative control surpassed the threshold value after the first month of storage with TBARS value of $0.660 \mathrm{mg}$ MDA/kg pork. In month 2 , light SCG (0.55 mg MDA/kg pork) reached the highest value of TBARS for all coffee treated pork for the entirety of testing.

The results in the present study contradict those by Nissen, Byrne, Bertelsen, \& Skibsted (2004) who reported that coffee provided little to no protection against LOX in comparison to 
rosemary extracts. This may be due to the 20 -fold difference between coffee extract concentration in the previous study $(0.05 \mathrm{~g} / \mathrm{kg})$ compared with the present study $(1 \mathrm{~g} / \mathrm{kg})$, and use of a different rosemary extract. The present study shows that all coffee combinations were as effective as rosemary oleoresin at inhibiting MDA production.

\subsection{Extent of lipid oxidation measured by gas chromatography}

Pork samples in the last 2 months of analysis exhibited the highest concentrations of hexanal with values ranging from $0.30-2.59 \mathrm{mg}$ hexanal $/ \mathrm{kg}$ pork, compared to octanal $(0.015$ $0.12 \mathrm{mg}$ octanal $/ \mathrm{kg}$ pork) and nonanal (0.036-0.13 mg nonanal $/ \mathrm{kg}$ pork) (Fig 2). Hexanal, the main aldehyde formed, was consistent with literature (Meynier, Genot, \& Gandemer, 1998), as it forms from oxidation of n- 6 fatty acids, specifically linoleic acid, the predominant polyunsaturated fatty acid in pork $(14.3 \mathrm{~g} / 100 \mathrm{~g})$. By month 3 , the negative control $(2.59 \mathrm{mg} / \mathrm{kg}$ pork) had the highest hexanal, while both light and dark roasts of LBC $(0.37$ and $0.39 \mathrm{mg} / \mathrm{kg}$ pork, respectively), inhibited hexanal production to the same extent as rosemary oleoresin $(0.30$ $\mathrm{mg} / \mathrm{kg}$ pork $)(\mathrm{p} \leq 0.05)$.

There was no significant difference for both octanal and nonanal from month 2 to 3 , which was consistent with a study done on beef by Lin, Toto, \& Were (2015). Despite the differences in study parameters (muscle types investigated and storage temperatures), octanal and nonanal displayed similar trends in both studies. Nonanal and octanal forms from oxidation of n-9 fatty acids, such as oleic acid. Although oleic acid $(34.3 \mathrm{~g} / 100 \mathrm{~g})$ is present in higher quantities in pork than linoleic acid $(14.3 \mathrm{~g} / 100 \mathrm{~g})$, monounsaturated fatty acids are more stable against oxidation than polyunsaturated fatty acids (Meynier, Genot, \& Gandemer, 1998). Amongst the coffee in pork treatments, there was no significant difference observed with the exception of month 3 for octanal. In month 3, the negative control displayed the highest octanal 
$(0.10 \mathrm{mg} / \mathrm{kg}$ pork $)$, while light LBC and rosemary oleoresin inhibited octanal formation $(0.017$ and $0.015 \mathrm{mg} / \mathrm{kg}$ pork, respectively). Volatile aldehydes are considered to be one of the most important products of LOX since they have such low threshold values for detection (Ladikos \& Lougovois, 1990). The rancidity thresholds for hexanal reported by Shahidi \& Pegg (1994) can range from $0.0045-0.15 \mathrm{mg} / \mathrm{kg}$ cooked pork. Although MDA flavor thresholds for rancidity were not surpassed (section 3.2), hexanal thresholds were exceeded by month 2 of storage by all treatments, with the lowest value for hexanal being observed by dark brew $(0.65 \mathrm{mg} / \mathrm{kg}$ pork $)$. Based on results from section 3.1, differing CGA levels had no effect on MDA formation since all added coffee in pork treatments produced similar results to rosemary oleoresin.

However, CGA and MRP levels correlated with greater AOX effect against volatile aldehydes in frozen cooked pork. The ranking for application form effectiveness against hexanal, octanal, and nonanal was as follows: LBC > WGC > SCG, corresponding with CGA and MRP concentrations found in Table 1.

\subsection{Protein oxidation measured by thiol content}

Thiol content increased from month 0 to $1(\mathrm{p} \leq 0.05)$ ranging in values from $0.56-0.96$ to $0.82-1.10 \mu \mathrm{mol} / \mathrm{g}$ protein, respectively. In month 2 , all treatments decreased in thiol content from month 1 ranging in values from $0.59-0.90 \mu \mathrm{mol} / \mathrm{g}$ protein. From month 2 to 3 , thiol content for negative control, rosemary oleoresin, and dark WGC increased, light LBC, dark SCG and LBC decreased, while light SCG and WGC remained relatively the same (Fig. 3). Thiol content was expected to gradually decrease or remain stable over the frozen storage period (Lund, Hviid, \& Skibsted, 2007; Nieto, Jongberg, Andersen, \& Skibsted, 2013). Despite unexpected increases in certain coffee in pork treatments, no significant difference amongst treatments were observed 
across the storage period $(\mathrm{p} \geq 0.05)$, indicating added coffee and Herbalox ${ }^{\circledR}$ HT-25 may not have a significant effect on POX.

Haak, Raes, \& De Smet (2009) found that $0.005-0.02 \%$ rosemary extract, tocopherols, and green tea extract did not influence POX in frozen cooked pork until day 8 of frozen storage. Whereas, Nieto, Jongberg, Andersen, \& Skibsted (2013) found that $0.05 \%$ and $0.4 \%$ of rosemary essential oil was able to protect against thiol loss in chilled raw pork throughout the 9 day storage. Lara, Gutierrez, Timon, \& Andres (2011) found that $0.03 \%$ rosemary and $0.1 \%$ lemon balm extracts in cooked meat exerted a protective effect against POX throughout storage. While these studies differ in design, which influences the extent of effectiveness of AOXs, our results correspond to other studies which indicate that rosemary oleoresin does not have an effect in inhibiting the loss of sulfhydryl content.

\subsection{Extent of protein oxidation measured by metmyoglobin formation}

An increase in metmyoglobin (MetMb) formation by 1-14\% over 3 months was observed (Fig 4). Significant differences were found amongst treatments for all testing months with the exception of month 1, which had \% MetMb range of 55.25-56.24\%. By month 3, rosemary oleoresin had lower MetMb $(54.47 \%)(\mathrm{p} \leq 0.05)$, while pork with added coffee were more similar to the negative control and ranged in values from $56.20-56.37 \%$, which indicates that coffee may not inhibit MetMb to the same extent as Herbalox ${ }^{\circledR}$ HT-25 in frozen cooked pork patties.

The overall range for MetMb for the entire study was 49.33-57.18\%. Fernandez-Lopez, Sevilla, Sayas-Barbera, Navarro, Marin, \& Perez-Alvarez (2003) found with fresh meat, values for MetMb initially ranged from 25-30\%. After cooking, these values increased to $32-45 \%$. At the end of the 8 day testing of chilled storage, Fernandez-Lopez, Sevilla, Sayas-Barbera, 
Navarro, Marin, \& Perez-Alvarez (2003) detected a distinct difference between control samples and added AOX samples with MetMb ranging from $70-75 \%$ and $42-48 \%$, respectively. In the present study, MetMb values for all treatments were higher on the initial day of testing (49.33$55.36 \%)$. However, the range of MetMb formed stayed relatively stable throughout frozen storage. The difference in results could have been due to frozen storage versus refrigerated storage.

Myoglobin oxidation in pork meat is predominantly affected by temperature and time (Faustman, Sun, Mancini, \& Suman, 2010). The pork in the present study was cooked prior to $18^{\circ} \mathrm{C}$ storage. The cooking could explain why MetMb values were initially higher. Greene, Hsin, \& Zipser (1971) found that MetMb levels exceeding $40 \%$ were rejected by consumers as a poor quality raw product, however, since these pork products are cooked, there is a wider range of acceptance since browning is expected with cooking. Denaturation of myoglobin unravels intact proteins, exposes heme iron. Oxidation of the centrally located iron, accounts for the higher MetMb values observed initially, which is expected to increase with extended storage periods. The reactive products of LOX, such as peroxides, promote myoglobin oxidation (Fernandez-Lopez, Sevilla, Sayas-Barbera, Navarro, Marin, \& Perez-Alvarez, 2003; Rhee, Anderson, \& Sams, 1996). The stable MetMb values could be explained by the slowing of oxidative reactions due to frozen storage.

\section{Conclusion}

The use of light and dark roasted coffee in spent ground, whole ground, and lyophilized brewed form at $1 \mathrm{~g}$ coffee/kg pork lowered MDA and hexanal in frozen cooked pork patties to the same extent as rosemary oleoresin, showing potential as an alternative AOX for LOX. In regards to POX, coffee AOXs neither had a positive nor negative impact on free thiol content or MetMb 
formation. The results show that all forms of both roast degrees could extend the shelf life of frozen cooked pork patties.

\section{6}

\section{Acknowledgments}

The authors would like to thank Tiffany Hashimoto for assistance with data collection, Andrew and Nathan at Rose Park Roasters for roasting the coffee, Mandeep Saini and Elizabeth Lawton at Farmer John ${ }^{\circledR}$ for providing the pork and assisting in preparing samples, and Chapman University for funding the research.

\section{References}

Abd El-Alim, S. S. L., Lugasi, A., Hovari, J., \& Dworschak, E. (1999). Culinary herbs inhibit lipid oxidation in raw and cooked minced meat patties during storage. Journal of the Science of Food and Agriculture, 79(2), 277-285.

AMSA. (1995). Research Guidelines for Cookery, Sensory Evaluation, and Instrumental Tenderness Measurements of Fresh Meat. Chicago, IL: American Meat Science Association.

AOAC. (2010). Official methods of analysis (18th ed). Arlington, VA: Association of Official Analysis Chemists International.

Bravo, J., Juaniz, I., Monente, C., Caemmerer, B., Kroh, L. W., Paz De Pena, M., \& Cid, C. (2012). Evaluation of spent coffee obtained from the most common coffeemakers as a source of hydrophilic bioactive compounds. Journal of Agricultural and Food Chemistry, 60(51), 12565-12573.

Budryn, G., \& Nebesny, E. (2013). Effects of green and roasted coffee antioxidants on quality and shelf life of cookies and chocolates. Journal of Food Processing and Preservation, 37(5), 835-845.

Dai, Y., Lu, Y., Wu, W., Lu, X. M., Han, Z. P., Liu, Y., . . Dai, R. T. (2014). Changes in oxidation, color and texture deteriorations during refrigerated storage of ohmically and water bath-cooked pork meat. Innovative Food Science and Emerging Technologies, 26, 341-346.

Del Pino-Garcia, R., Gonzalez-SanJose, M. L., Rivero-Perez, M. D., \& Muniz, P. (2012). Influence of the Degree of Roasting on the Antioxidant Capacity and Genoprotective Effect of Instant Coffee: Contribution of the Melanoidin Fraction. Journal of Agricultural and Food Chemistry, 60(42), 10530-10539.

Delgado-Andrade, C., Rufian-Henares, J. A., \& Morales, F. J. (2005). Assessing the antioxidant activity of melanoidins from coffee brews by different antioxidant methods. Journal of Agricultural and Food Chemistry, 53(20), 7832-7836.

Eymard, S., Baron, C. P., \& Jacobsen, C. (2009). Oxidation of lipid and protein in horse mackerel (Trachurus trachurus) mince and washed minces during processing and storage. Food Chemistry, 114(1), 57-65. 
Farah, A. (2012). Coffee Constituents. In Y.-F. Chu (Ed.), Coffee: Emerging health effects and disease prevention (1st ed., pp. 21-58): Blackwell Publishing Ltd.

Faustman, C., Sun, Q., Mancini, R., \& Suman, S. P. (2010). Myoglobin and lipid oxidation interactions: Mechanistic bases and control. Meat Science, 86(1), 86-94.

Fernandez-Lopez, J., Sevilla, L., Sayas-Barbera, E., Navarro, C., Marin, F., \& Perez-Alvarez, J. A. (2003). Evaluation of the antioxidant potential of hyssop (Hyssopus officinalis L.) and rosemary (Rosmarinus officinalis L.) extracts in cooked pork meat. Journal of Food Science, 68(2), 660-664.

Georgantelis, D., Ambrosiadis, I., Katikou, P., Blekas, G., \& Georgakis, P. A. (2007). Effect of rosemary extract, chitosan and alpha-tocopherol on microbiological parameters and lipid oxidation of fresh pork sausages stored at 4 degrees C. Meat Science, 76(1), 172-181.

Gray, J. I., \& Pearson, A. M. (1987). Rancidity and warmed-over flavor. In Handbook of Meat, Poultry and Seafood Quality, vol. 3 (pp. 221-269). New York: Van Nostrand Reinhold Co.

Greene, B. E., Hsin, I. M., \& Zipser, M. W. (1971). Retardation of oxidative color changes in raw ground beef. Journal of Food Science, 36(6), 940-942.

Haak, L., Raes, K., \& De Smet, S. (2009). Effect of plant phenolics, tocopherol and ascorbic acid on oxidative stability of pork patties. Journal of the Science of Food and Agriculture, 89(8), 1360-1365.

Kim, H., Cadwallader, K. R., Kido, H., \& Watanabe, Y. (2013). Effect of addition of commercial rosemary extracts on potent odorants in cooked beef. Meat Science, 94(2), 170-176.

Kingston, E. R., Monahan, F. J., Buckley, D. J., \& Lynch, P. B. (1998). Lipid oxidation in cooked pork as affected by vitamin E, cooking and storage conditions. Journal of Food Science, 63(3), 386-389.

Ladikos, D., \& Lougovois, V. (1990). Lipid oxidation in muscle foods: A review. Food Chemistry, 35(4), 295-314.

Lara, M. S., Gutierrez, J. I., Timon, M., \& Andres, A. I. (2011). Evaluation of two natural extracts (Rosmarinus officinalis L. and Melissa officinalis L.) as antioxidants in cooked pork patties packed in MAP. Meat Science, 88(3), 481-488.

Lin, C., Toto, C., \& Were, L. (2015). Antioxidant effectiveness of ground roasted coffee in raw ground top round beef with added sodium chloride. LWT-Food Science and Technology, 60(1), 29-35.

Ludwig, I. A., Sanchez, L., Caemmerer, B., Kroh, L. W., Paz De Pena, M., \& Cid, C. (2012). Extraction of coffee antioxidants: Impact of brewing time and method. Food Resesarch International, 48(1), 57-64.

Lund, M. N., Hviid, M. S., \& Skibsted, L. H. (2007). The combined effect of antioxidants and modified atmosphere packaging on protein and lipid oxidation in beef patties during chill storage. Meat Science, 76(2), 226-233.

Martens, H., Stabursvik, E., \& Martens, M. (1982). Texture and color changes in meat during cooking related to thermal-denaturation of muscle proteins. Journal of Texture Studies, 13(3), 291-309.

Meynier, A., Genot, C., \& Gandemer, G. (1998). Volatile compounds of oxidized pork phospholipids. Journal of the American Oil Chemists Society, 75(1), 1-7. 
Nicoli, M. C., Anese, M., Manzocco, L., \& Lerici, C. R. (1997). Antioxidant properties of coffee brews in relation to the roasting degree. LWT-Food Science and Technology, 30(3), 292297.

Nieto, G., Jongberg, S., Andersen, M. L., \& Skibsted, L. H. (2013). Thiol oxidation and protein cross-link formation during chill storage of pork patties added essential oil of oregano, rosemary, or garlic. Meat Science, 95(2), 177-184.

Nissen, L. R., Byrne, D. V., Bertelsen, G., \& Skibsted, L. H. (2004). The antioxidative activity of plant extracts in cooked pork patties as evaluated by descriptive sensory profiling and chemical analysis. Meat Science, 68(3), 485-495.

Nolan, N. L., Bowers, J. A., \& Kropf, D. H. (1989). Lipid oxidation and sensory analysis of cooked pork and turkey stored under modified atmopsheres. Journal of Food Science, 54(4), 846-849.

Rhee, K. S., Anderson, L. M., \& Sams, A. R. (1996). Lipid oxidation potential of beef, chicken, and pork. Journal of Food Science, 61(1), 8-12.

Rojas, M. C., \& Brewer, M. S. (2007). Effect of natural antioxidants on oxidative stability of cooked, refrigerated beef and pork. Journal of Food Science, 72(4), S282-S288.

Salminen, H., Estevez, M., Kivikari, R., \& Heinonen, M. (2006). Inhibition of protein and lipid oxidation by rapeseed, camelina and soy meal in cooked pork meat patties. European Food Research and Technology, 223(4), 461-468.

SAS Institute. (2011). The SAS system for Windows (Version 9.3). Cary, NC, USA.

Sasse, A., Colindres, P., \& Brewer, M. S. (2009). Effect of natural and synthetic antioxidants on the oxidative stability of cooked, frozen pork patties. Journal of Food Science, 74(1), S30-S35.

Shahidi, F., \& Pegg, R. B. (1994). Hexanal as an indicator of the flavor deterioration of meat and meat-products. Lipids Food Flavors, 558, 256-279.

Sheard, P. R., Enser, M., Wood, J. D., Nute, G. R., Gill, B. P., \& Richardson, R. I. (2000). Shelf life and quality of pork and pork products with raised n-3 PUFA. Meat Science, 55(2), 213-221.

Tang, J., Faustman, C., \& Hoagland, T. A. (2004). Krzywicki revisited: Equations for spectrophotometric determination of myoglobin redox forms in aqueous meat extracts.. Journal of Food Science, 69(9), C717-C720.

Teets, A. S., \& Were, L. M. (2008). Inhibition of lipid oxidation in refrigerated and frozen salted raw minced chicken breasts with electron beam irradiated almond skin powder. Meat Science, 80, 1326-1332

Viljanen, K., Kivikari, R., \& Heinonen, M. (2004). Protein-lipid interactions during liposome oxidation with added anthocyanin and other phenolic compounds. Journal of Agricultural and Food Chemistry, 52(5), 1104-1111. 


\section{$1 \quad$ Tables}

2 Table 1: Maillard reaction products, metal chelation and chlorogenic acid concentration for spent 3 ground, whole ground, and lyophilized brew form coffee solutions.

4 
5 Table 1

\begin{tabular}{lcccc}
\hline & $\begin{array}{c}\text { MRPs }^{\mathrm{a}} \\
\left(\begin{array}{c}\text { Absorbance } \\
\text { intensity } \\
\text { units })\end{array}\right.\end{array}$ & $\begin{array}{c}\text { Metal chelation }^{\mathrm{b}} \\
(\mu \mathrm{mol} \mathrm{EDTA} / \mathrm{g} \\
\text { coffee } \\
\text { equivalents })\end{array}$ & $\begin{array}{c}\text { 3-CGA } \\
(\mathrm{mg} / \mathrm{g} \text { coffee })\end{array}$ & $\begin{array}{c}\text { Total 3-CGA } \\
(\mathrm{mg} / \mathrm{g} \text { coffee })\end{array}$ \\
\hline Light & $0.73 \pm 0.012$ & $14.05 \pm 1.48$ & 1.98 & 21.00 \\
$\quad$ Spent & $1.23 \pm 0.012$ & $24.00 \pm 6.96$ & 4.70 & \\
$\quad$ Ground & $4.80 \pm 0.14$ & $58.38 \pm 2.29$ & 14.32 & \\
$\quad$ Lyophilized Brew & & & & \\
Medium & $1.42 \pm 0.024$ & $21.43 \pm 0.70$ & 2.01 & \\
$\quad$ Spent & $1.47 \pm 0.017$ & $24.23 \pm 0.76$ & 6.83 & \\
$\quad$ Ground & $5.91 \pm 0.15$ & $43.67 \pm 2.83$ & 7.28 & \\
$\quad$ Lyophilized Brew & & & & \\
& & & & \\
Dark & & & & \\
$\quad$ Spent & $1.75 \pm 0.019$ & $30.97 \pm 1.65$ & 1.86 & \\
$\quad$ Ground & $2.22 \pm 0.013$ & $26.79 \pm 1.95$ & 4.40 & \\
$\quad$ Lyophilized Brew & $5.83 \pm 0.47$ & $35.94 \pm 1.02$ & 5.90 & \\
\hline
\end{tabular}

$6{ }^{\mathrm{a}}$ Brown nitrogenous Maillard reaction products from hot brewed coffee at $1 \mathrm{~g}$ coffee $/ 100 \mathrm{~mL}$ 7 measured at $420 \mathrm{~nm}$

$8 \quad{ }^{\mathrm{b}}$ Metal chelation by ferrozine assay for hot brewed coffee at $0.1 \mathrm{~g}$ coffee $/ 100 \mathrm{~mL}$ measured at $9562 \mathrm{~nm}$

$10{ }^{\mathrm{c}}$ Chlorogenic acid content by HPLC analysis for cold brewed coffee at $0.1 \mathrm{~g} / 100 \mathrm{~mL}$ 
2 Fig. 1. Thiobarbituric acid reactive substances/TBARS (mg MDA/kg pork) \pm standard deviation

3 with negative control (no antioxidants added), coffee in pork treatments $(1 \mathrm{~g} / \mathrm{kg}$ light and dark

4 roasts of spent, whole, lyophilized brewed) and rosemary oleoresin $(2 \mathrm{~g} / \mathrm{kg})$ in cooked pork

5 patties analyzed monthly over 3 months of frozen storage. Means followed by the same letter between samples for each month are not significantly different (Duncan's multiple range test $\mathrm{p} \leq$ 7 0.05).

8 Fig. 2. Key volatile aldehyde ( $\mathrm{mg} / \mathrm{kg}$ cooked pork) for negative control (no antioxidants added), coffee in pork treatments $(1 \mathrm{~g} / \mathrm{kg}$ light and dark roasts of spent, whole, lyophilized brewed), and rosemary oleoresin $(2 \mathrm{~g} / \mathrm{kg})$ in cooked pork patties analyzed after 2 months of frozen storage.

Fig.3. Thiol content ( $\mu \mathrm{mol}$ thiol/g pork) \pm standard deviation for negative control (no antioxidants added), coffee in pork treatments $(1 \mathrm{~g} / \mathrm{kg}$ light and dark roasts of spent, whole, lyophilized brewed), and rosemary oleoresin $(2 \mathrm{~g} / \mathrm{kg})$ in cooked pork patties analyzed monthly over 3 months of frozen storage.

Fig. 4. Percent metmyoglobin for negative control (no antioxidants added), coffee in pork treatments $(1 \mathrm{~g} / \mathrm{kg}$ light and dark roasts of spent, whole, lyophilized brewed), and rosemary oleoresin $(2 \mathrm{~g} / \mathrm{kg})$ in cooked pork patties analyzed monthly over 3 months of frozen storage. Means followed by the same letter between the samples for each month are not significantly different (Duncan's multiple range test $\mathrm{p} \leq 0.05$ ). Error bars represent standard deviation. 


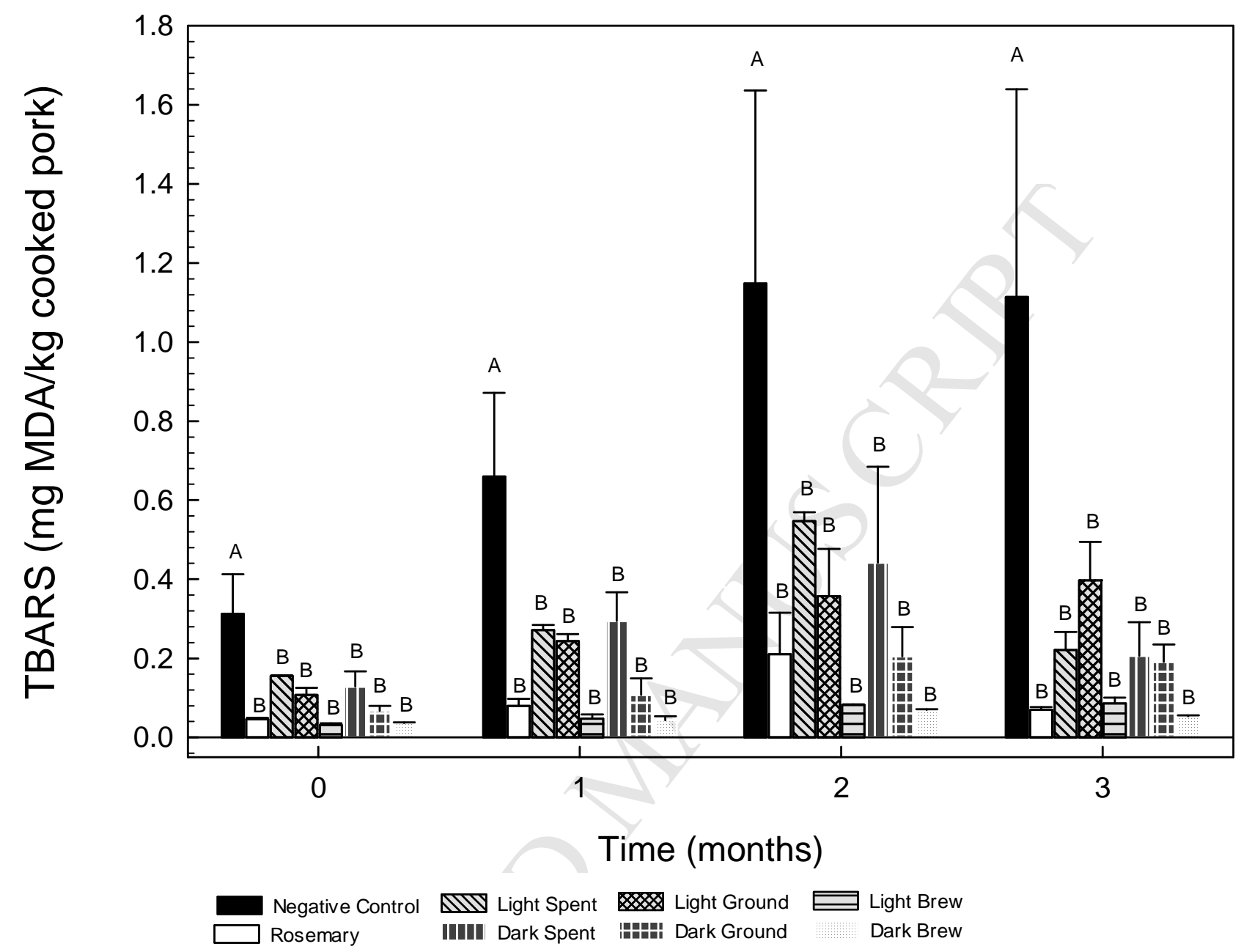

23 Fig. 1. 
A) Hexanal

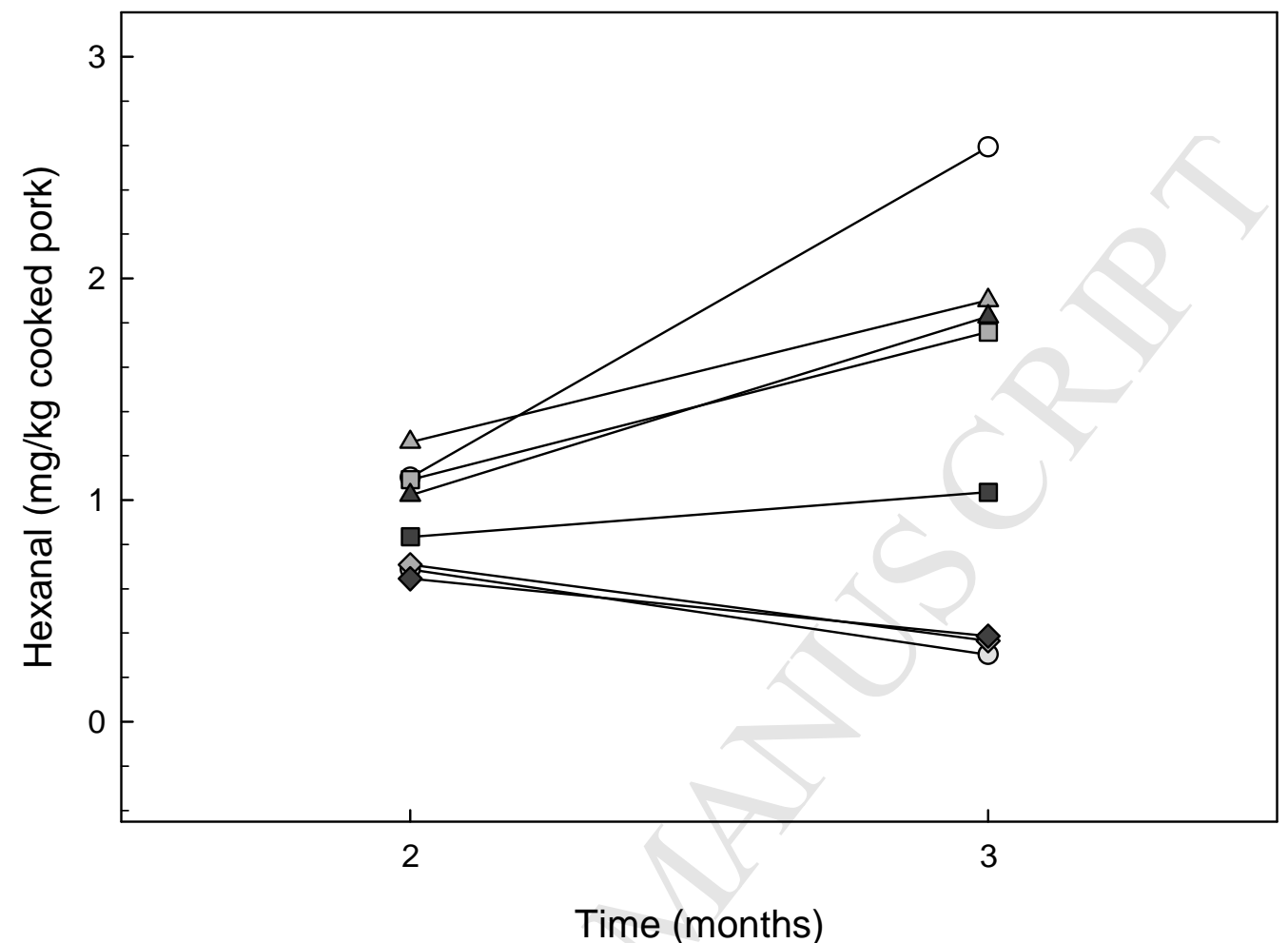

\section{B) Octanal}

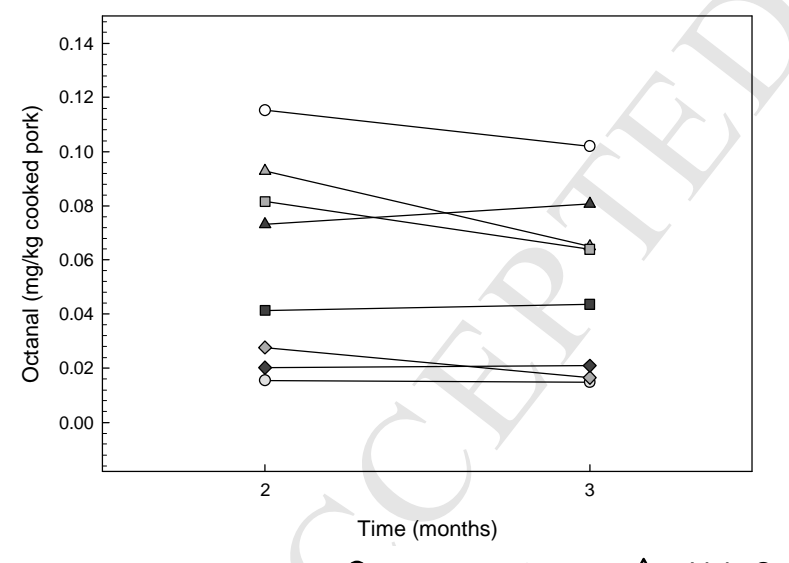

C) Nonanal

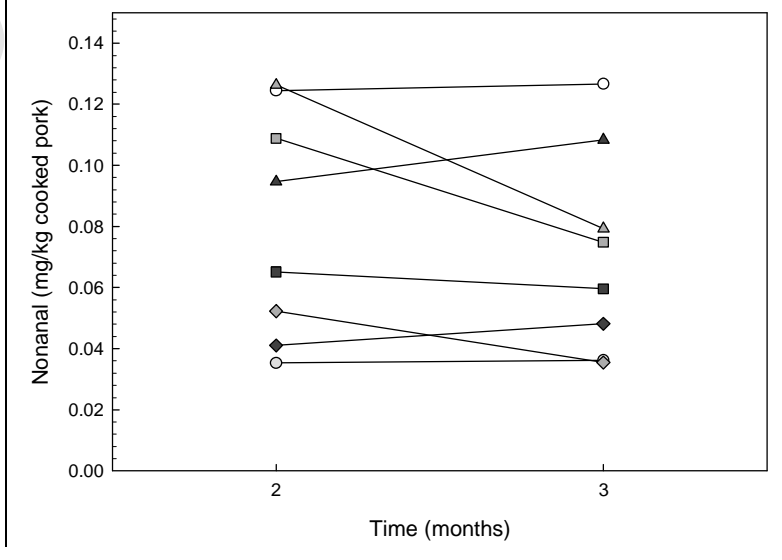

$-\bigcirc$ Negative Control $-\triangle$ Light Spent $-\square-$ Light Ground $\checkmark-$ Light Brew $\neg$ - Rosemary $\triangle$ Dark Spent $\neg-$ Dark Ground $\prec$ Dark Brew

Fig. 2. 


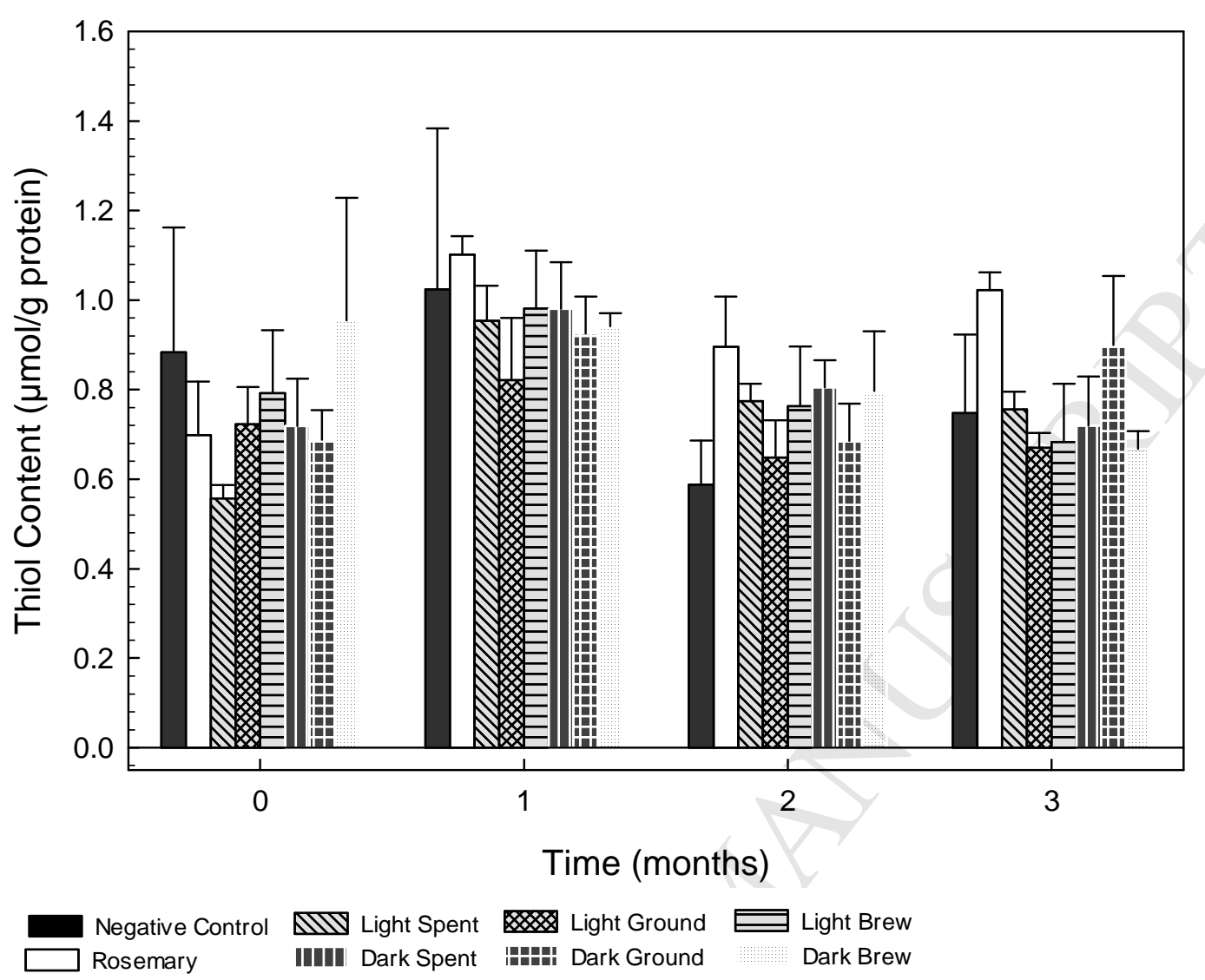

Fig. 3. 


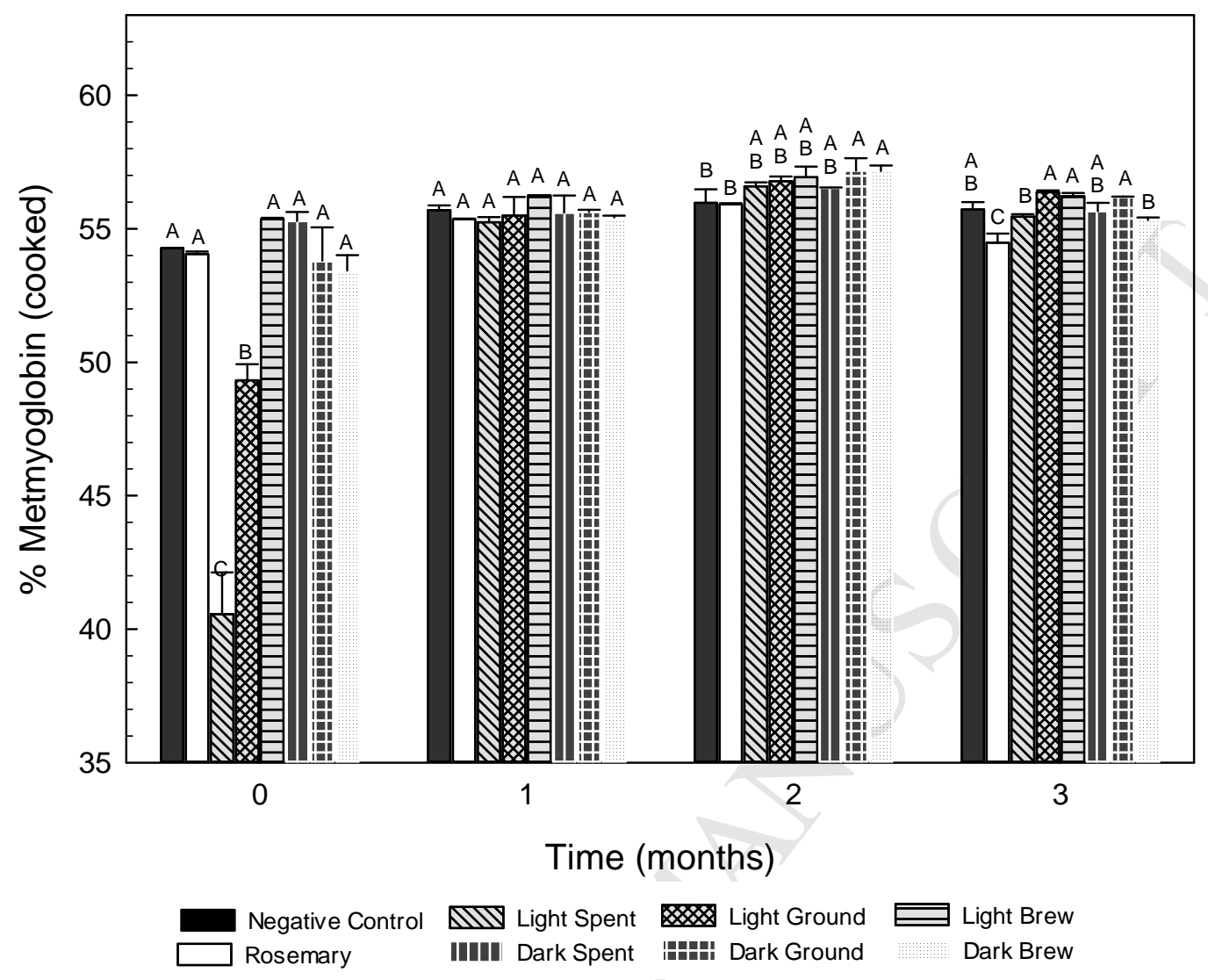

Fig. 4. 
Highlights:

- Pork with coffee exhibited comparable TBARS values to pork with rosemary oleoresin.

- Aldehydes were lowest with added lyophilized brew compared to whole or spent coffee.

- Thiol content remained stable for all treatments under frozen conditions.

- Coffee inhibited lipid oxidation without adverse effects on protein oxidation. 